\title{
Professionalism perspectives among medical students of a novel medical graduate school in Malaysia
}

Mainul Haque,' Zainal Zulkifli, ${ }^{2}$

Seraj Zohurul Haque, ${ }^{3}$

Zubair M Kamal, ${ }^{4}$ Abdus Salam, ${ }^{5}$

Vidya Bhagat, ${ }^{2}$ Ahmed Ghazi

Alattraqchi, ${ }^{2}$ Nor Iza A Rahman ${ }^{2}$

'Unit of Pharmacology, Faculty of Medicine and Defense Health, National Defense University of Malaysia, Kem Sungai Besi, Kuala Lumpur, Malaysia; ${ }^{2}$ Faculty of Medicine, Universiti Sultan Zainal Abidin, Jalan Sultan Mahmud, Kuala Terengganu, Terengganu, Malaysia; ${ }^{3} \mathrm{~S} c h o o l$ of Medicine, University of Dundee, Ninewells Hospital \& Medical School, Dundee, UK; ${ }^{4}$ Sleep Research Unit, Toronto Western Hospital, University Health Network, Toronto, ON, Canada; ${ }^{5}$ Department of Medical Education, Universiti Kebangsaan Malaysia Medical Centre, Cheras, Kuala Lumpur, Malaysia

\section{Video abstract}

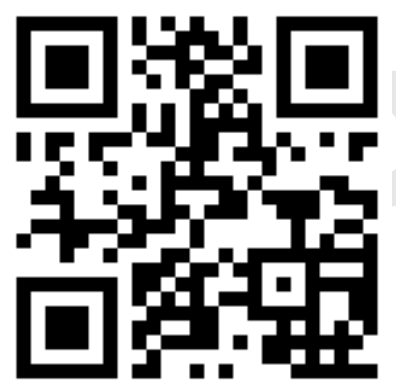

Point your SmartPhone at the code above. If you have a QR code reader the video abstract will appear. Or use: http://youtu.be/wym-42mCZpY

Correspondence: Mainul Haque

Unit of Pharmacology, Faculty of Medicine and Defense Health, National Defense University of Malaysia, Kem Sungai Besi, 57000 Kuala Lumpur, Malaysia

Tel +60 109265543

Email runurono@gmail.com
This article was published in the following Dove Press journal:

Advances in Medical Education and Practice

25 July 2016

Number of times this article has been viewed

Abstract: Defining professionalism in this constantly evolving world is not easy. How do you measure degrees of benevolence and compassion? If it is so obvious to our profession, what professionalism is, then why is it so difficult to teach it to medical students and residents? Today's definition of medical professionalism is evolving - from autonomy to accountability, from expert opinion to evidence-based medicine, and from self-interest to teamwork and shared responsibility. However, medical professionalism is defined as the basis for the trust in the patient-physician relationship, caring and compassion, insight, openness, respect for patient dignity, confidentiality, autonomy, presence, altruism, and those qualities that lead to trust-competence, integrity, honesty, morality, and ethical conduct. The purpose of this study is to explore professionalism in terms of its fundamental elements among medical students of Universiti Sultan Zainal Abidin (UniSZA). This was a cross-sectional study carried out on medical students of UniSZA. The study population included preclinical and clinical medical students of UniSZA from Year I to Year V of academic session 2014/2015. The simple random sampling technique was used to select the sample. Data were collected using a validated instrument. The data were then compiled and analyzed using SPSS Version 21. Out of 165 questionnaires distributed randomly among Year I to Year V medical students of UniSZA, 144 returned, giving a response rate of $87 \%$. Among the study participants, $38 \%$ (54) and 62\% (90) were males and females, respectively. The grand total score was $170.92 \pm 19.08$. A total of $166.98 \pm 20.15$ and $173.49 \pm 18.09$ were the total professionalism score of male and female study participants, respectively, with no statistically significant $(P=0.61)$ differences. This study found almost similar levels of familiarity with all fundamental issues of professionalism with no statistically $(P>0.05)$ significant differences. Medical faculty members should give more effort for the professional development of medical doctor. Henceforth, researchers believe and expect that the country will produce more rational and holistic medical doctors. Keywords: professionalism, perspectives, medical students, Malaysia

\section{Introduction}

Medical professionalism is defined as "commitment to carrying out professional responsibilities, adherence to ethical principles and sensitivity to a diverse patient population" by the Accreditation Council for Graduate Medical Education, USA. ${ }^{1}$ The Merriam-Webster dictionary defines professionalism as "the conduct, aims, or qualities that characterize or mark a profession or a professional person"; and it defines a profession as "a calling requiring specialized knowledge and often long and intensive academic preparation". ${ }^{2}$ It also defined as "as a vocation or calling, especially one involving a degree of skill, learning or science. Another helpful description is that of a trade or occupation pursued for higher motives, to a proper standard". 3 
The term professionalism is used to describe those skills, attitudes and behaviors which we have come to expect from individuals $[\ldots]$ concepts such as maintenance of competence, ethical behavior, integrity, honesty, altruism, service to others, adherence to professional codes, justice, respect for others, self-regulation, etc. ${ }^{4}$

Defining professionalism in this constantly evolving world is not an easy work.

How do you measure degrees of benevolence and compassion? If it is so obvious to our profession, what professionalism is, then why is it so difficult to teach it to medical students and residents?

Today's definition of medical professionalism is evolving from autonomy to accountability, from expert opinion to evidence-based medicine, from self-interest to teamwork and shared responsibility. ${ }^{6}$

However, medical professionalism is defined as the basis for the trust in the patient-physician relationship, caring and compassion, insight, openness, respect for patient dignity, confidentiality, autonomy, presence, and altruism, in addition to those qualities that lead to trust-competence, integrity, honesty, morality, and ethical conduct. ${ }^{7-9}$

Professional competence is the habitual and judicious use of communication, knowledge, technical skills, clinical reasoning, emotions, values, and reflection in daily practice for the benefit of the individual and the community being served. ${ }^{10}$

Modern medicines promote more patient-centered and shared decision-making approach. In these days,

[...] professionalism includes the ability to communicate specialist knowledge, diagnosis and treatment options in an easy-to-understand way, rather than seeking to use expert knowledge as a means to create distance from, and a dependency of, the public. Professionalism also involves confidentiality, continuity, trust, honesty, and compassion. ${ }^{3}$

The practice of medicine is not a business and can never be such. Our fellow creatures cannot be dealt with as a man deals in corn and coal; the human heart by which we live must control our professional relations. ${ }^{11}$

The self-interest issue in the modern world started working as potent forces of a political, legal, and market-driven nature is producing great stress on the practice of medicine, reducing the public respect toward the Healer role of medical practitioners. ${ }^{12-14}$ All of these issue have contributed to the development of the medical charter which can be considered as Hippocratic Oath of the modern era, that emphasizes more on defining and developing professionalism. That is how we conduct ourselves as physicians while serving our patients and society in our roles as a healer, as a medical professional, and/or as a medical scientist. ${ }^{15-18}$ There also comes nature vs nurture theory. ${ }^{19}$ Professionalism can be taught in the classroom, or the qualities required to meet the professional ideals, such as selflessness, empathy, and benevolence, have to be an innate quality of an individual, ${ }^{20}$ and admission system has to figure out a way to identify those ideas and help flourish it because medical educators can preach altruism, but it cannot transform a student's personality. ${ }^{20,21}$

Medical students are future medical doctors, and very soon they are going to "the final frontier" 22 to be exposed to a situation where patient care is influenced by different healthrelated profit-making corporate groups. ${ }^{22,23}$ The link between a medical doctor and pharmaceutical industry, the most important stakeholder in any health care system, has been changed not only in private practice but also in public hospitals in the last few decades. ${ }^{22}$ Actually, the secret relationship with the pharmaceutical industry and medical doctors was first described in 1961 in an article written by Doctor Charles D May published in the Journal of Medical Education. ${ }^{24}$ It has been discussed in different reputed journals that the pharmaceutical industry spends between US\$27 and US\$57 billion every year on drug promotion, ${ }^{25-28}$ but global promotional activity costs $>$ US $\$ 70$ billion. ${ }^{29}$ Medicinal manufacturing companies use $15 \%-20 \%$ of its yearly financial plan for promoting their products. ${ }^{30}$ Previous studies reported back in the 1990s stated that the industry spends US\$8,000-13,000 for each medical doctor every year. ${ }^{31,32}$

Unlike the door-to-door vendors of cosmetics and vacuum cleaners, drug reps do not sell their product directly to buyers. Consumers pay for prescription drugs, but physicians control access. Drug reps increase drug sales by influencing physicians, and do so with finely titrated doses of friendship. ${ }^{33}$

Reps may be genuinely friendly, but they are not genuine friends. Drug reps are selected for their present ability and outgoing natures and are trained observant, personable, and helpful. [...] to assess physicians' personalities, practice styles, and preferences, and relay this information back to the Company. ${ }^{33}$

Another study suggested that doctors meet pharmaceutical promoters at least two to four times a month. ${ }^{34-36}$ Very often, medical doctors accept gifts, such as drug samples, stationery, dinner in very high-class restaurants, joining industry-funded continuing medical education program, 
and travel or accommodation in the fabulous resort from pharmaceutical sales representative. ${ }^{35,37-39}$

The commercial needs of countless, and fiercely competing pharmaceutical companies has led them to depend on the tried and tested 3Cs: Convince, if possible, confuse if necessary and corrupt if nothing else works. Chandra Gulhati, Editor, MIMS India. ${ }^{40}$

It's my job to figure out what a physician's price is. For some it's dinner at the finest restaurant, $[. .$.$] them prescribe confi-$ dently and for others it's my attention and friendship, but at the most basic level, everything is for sale, and everything is an exchange. ${ }^{33}$

"During training, I was told, when you're out to dinner with a doctor, 'The physician is eating with a friend. You are eating with a client"', 33

There have also been shameful misconducts by members of the profession for personal gains, which include fudging of trial results to favor the sponsors and the prescription of drugs unnecessarily to patients. ${ }^{41}$

"Anyone who says that the drug company is discussing of doctor's carries no influence is joking, astonishingly naive, or deliberately trying to mislead" ${ }^{42}$ An aggressive drug promotional activity over and over again changes the prescribing behavior toward costly patent-branded medicine of generics, thereby causing rapid booms of the cost of medical care and many occasional irrational prescribing. ${ }^{35,36,43-49}$ It has been reported that physicians were so much influenced that they later asked to include some particular branded medicine to incorporate in hospital guidelines. ${ }^{44}$ Accepting gifts not only promotes industry's profit but also damages the great professional respect of medical doctors. Therefore, physicians are increasingly losing trust from their patients. ${ }^{35,50}$ Henceforth, a number of the expert group suggested more control of medicine profile-raising accomplishments because pharmaceutical industry very often provides misleading information. ${ }^{51-58}$ There are numerous reports published in highly reputed journals throughout the world medical professionalism, and commitment of medical doctor is grind down when physicians are accepting financial incentives and a gift from pharmaceutical and other profitmaking organizations. ${ }^{34,47,48,54,59-66}$ The most concerning issue is that medical students are also receiving gifts

[...] in spite of medical schools' efforts to shield budding doctors from the dark forces of the medical-industrial complex, more than half of medical students end up receiving gifts from pharmaceutical representatives by the end of their fourth year,
According to an upcoming study. ${ }^{67}$ A number of studies reported that the majority of medical students (85\%) felt that it is immoral to receive gift worth of US\$50 for politician, but only $<50 \%$ of medical students and professionals claimed that it was unbefitting to accept the gift of the same cost. ${ }^{51,68}$

Ethics, in general, is a philosophical issue and is defined as the philosophical study of morality. The scientific study of morality is descriptive ethics, and it is generally concerned with the explanation of moral views and its causal origin. ${ }^{69}$

Medical ethics and values should be the basic stratagems to govern every decision in medical practice and patient care. ${ }^{70}$ One Indian medical ethics journal commented that

[...] corruption, an undeniable reality in the health sector, is arguably the greatest ethical crisis in medicine today. However, it remains poorly addressed in scholarly journals and by professional associations of physicians and bio-ethicists. ${ }^{71}$

In modern era, medical doctors usually after graduation take an oath to safeguard their patients from harmful and waggish activities, and such oath has been in practice since the time of Hippocrates. Hippocratic Oath guides the premier objective of the medical profession. It talks about not only obligations concerning the patient but also responsibilities headed for fellow colleagues of medicine. Overall, Hippocratic Oath discusses the medical professional's commitment to give comfort and relief and not to cause any kind of harm to the patient. ${ }^{72}$ Medical professionalism promotes the ethical and moral duties and responsibilities of a doctor to his/her patients. ${ }^{73}$ Therefore, high standard of ethical principles and practice among physicians as individual and business are expected to form the bridge between doctors and the community. ${ }^{74-76}$ "There is definitely a decline in ethics in the field of Medicine and in the society as a whole". ${ }^{77}$ Especially "when financial considerations enter into medical decisions, values are always brought into question". ${ }^{78}$ Medical doctors are pebbledash enormous criticism because the medical professionalism is declining throughout the world because of changed health care policy and practice. ${ }^{79}$ The basis of professionalism must be restored back to its original position, as a medical doctor it is expected to be moral and highly professional, by any individual and also broader societies. ${ }^{76}$ Henceforth, teaching medical professionalism and the ethical issue should be started as early as possible in medical school. As it is believed that morality should be taught in the initial days of life, ${ }^{80-83}$ it has been reported that

the medical ethics curriculum can be improved by focusing it on professional formation as preparation for a lifelongcommitment to professionalism in patient care, education, 
and research. [...] preserves its status as a caring profession

that situates the needs of patients as its top priority. ${ }^{84}$

A number of studies advised to incorporate medical professionalism and ethics in the undergraduate medical curriculum, especially in public health and family medicine module to prepare high-quality doctors in their community ${ }^{85-90}$ To best of our knowledge, there are only six studies identified: four studies involving medical students, one study involving medical resident in a public hospital in Malaysia, and the remaining one study involving medical doctor and association. ${ }^{91-96}$ The Faculty of Medicine, Universiti Sultan Zainal Abidin (UniSZA), is scheduled to conduct a major revision in the next few years of the undergraduate medical curriculum. ${ }^{97,98}$ The medical faculty of the UniSZA has evolved with time. It initially started as a faculty of health sciences, offering three diploma programs in radiography, medical laboratory technology, and nursing science. UniSZA was honored with the trust given by the Ministry of Higher Education of the Government of Malaysia to contribute toward the development and improvement of health care by the approval of the university's medical program in Kuala Terengganu, Terengganu, Malaysia. The approval was granted by the Ministry of Higher Education on February 3, 2009. Faculty had already started one degree program, Dietetics (Honors) in 2008; MBBS (Bachelor Medicine and Bachelor of Surgery) became a part of the program in 2009. In 2011, a Diploma in Physiotherapy was added to existing diploma programs. It is expected that faculty will admit new groups of students in 2015 into another three new programs: 1) Bachelor of Biomedicine, 2) Bachelor of Medical Imaging and Diagnostics, and 3) Bachelor of Nutrition. The first group of 30 Medicine and Bachelor of Surgery students, admitted in 2009, graduated in August 2014. UniSZA medical graduates started working as house officers and serving Malaysia from early 2015. The aim of this study is to explore the personal evaluation of professionalism in terms of its fundamental elements among UniSZA medical students and to equate any variances of professionalism between sexes and years of study. Malaysian medical education usually of 5 years program and 2 years housemanship (internship or foundation year) in hospitals owned by the Ministry of Health, Government of Malaysia. ${ }^{99-101}$ Therefore, this exercise is to ensure that a highly professional and committed medical doctor is produced for Malaysian community. This study provides suitable data to design a new educational program to equip our students.

\section{Materials and methods}

This was a cross-sectional study conducted on medical students of UniSZA. The study population was preclinical and clinical medical students of UniSZA from Year I to Year V of academic session 2014/2015. The sample size was calculated 169 among 300 total medical students of Faculty of Medicine, UniSZA, using a sample size calculator. ${ }^{102}$ Another $10 \%$ nonresponse rate was added to encounter the missing value of questionnaires that resulted to 186 of total subjects. The simple random sampling technique was used to select the sample. Unfortunately, when data were collected in a predecided time in the lecture hall, only 165 students turned out, rest of the 21 students, although properly informed, did not come to participate in this study. Therefore, 165 questionnaires (Figure S1) were distributed among the students. The period of study was September to October 2015. Data were collected using a validated instrument. ${ }^{93,94}$ Although the instrument was developed and validated in another public university in Malaysia, but the questionnaire was again pretested and validated for the medical students of UniSZA. ${ }^{91}$ As no change was required precisely the same questionnaire was maintained of Universiti Kebangsaan Malaysia to conduct the study after revalidation in UniSZA. Most of the sections of this questionnaire demonstrated acceptable values, with a range between 0.672 and 0.882 , which indicated that both instruments possessed good internal consistency and reliability. The evidence of convergent validity was shown by the significant correlations between the items of each section and the overall mean in each section $\left(r_{\mathrm{s}}=0.332-0.718\right.$; $P<0.05) .{ }^{103,104}$ The questionnaire contained nine core elements of professionalism attributes, such as honesty, accountability, confidentiality, respectfulness, responsibility, compassion, communication, maturity, and self-directed learning. There was a range of statements under each professionalism core element that was measured by 5-point Likert scale, giving a maximum score of 220. The mean of all nine attributes' scores represented the professionalism of respondents as a whole. The instrument also contained four open-ended questions exploring about respondents' opinion on what professionalism meant to them, how professionalism should be taught, how they learned professionalism, and how professionalism should be assessed. The data were then compiled and analyzed using SPSS Version 21 (IBM Corporation, Armonk, NY). This research obtained the certificate of ethical approval from UniSZA Research Ethics Committee (UHREC) [UniSZA, C/1/UHREC/628-1 (39), August 3, 2015]. Research ethics were strictly maintained, especially regarding confidentiality. Explanation concerning the purpose of the study was given, and informed consent was obtained verbally from the participants to utilize their data for research purposes. UHREC had examined the questionnaire before the study was started and was satisfied that there were no sensitive questions. The current research was totally anonymous and voluntary. Thus, researchers thought that verbal informed consent was sufficient. The principal investigator 
informed UHREC and took formal permission for the verbal consent procedures before data collection began. The principal investigator Professor (Dr) Mainul Haque was an academic staff of UniSZA when the current research was conducted and this article was accepted.

\section{Results}

Out of 165 questionnaires distributed randomly among Years I-V medical students of UniSZA, 144 returned, giving a response rate of $87 \%$. Among the study participants, $38 \%(54)$ and $62 \%$ (90) were male and female, respectively. A total of $65 \%$ (94), 17\% (25), 17\% (24), and 1\% (1) of the study participants were from Malay, Chinese, Indian, and other races, respectively. A total of $66 \%$ (95), 15\% (21), $12 \%$ (18), 5\% (7), and 2\% (3) of the study participants have their religion as Islam, Buddha, Hindu, Christian, and others, respectively. Again, the study participants were 20\% (29), 23\% (33), 17\% (24), 19\% (27), and 21\% (31) from Year I, Year II, Year III, Year IV, and Year V, respectively. A total of $43 \%$ (62) and $57 \%$ (82) of the study participants were from Phase I (basic sciences) and Phase II (clinical medicine), respectively. A total of 5\% (7), 4\% (6), 11\% (16), 5\% (7), 9\% (12), $6 \%(9)$, and $60 \%$ (87) of the study participants obtain grades A, B+, B, C+, C, passed, and not stated, respectively, in the last examination (Table 1 and Figure 1). UniSZA Faculty of Medicine has its' own unique grading policy (Table S1).

The total mean scores were $22.44 \pm 3.43,18.38 \pm 2.95$, $15.56 \pm 3.01,24.45 \pm 3.11,23.13 \pm 2.91,16.51 \pm 4.85,18.75 \pm 3.10$, $23.77 \pm 3.20$, and $8.13 \pm 1.42$ for honesty, accountability, confidentiality, respectfulness, responsibility, compassion, communication, maturity, and self-directed learning, respectively, and the grand total was $170.92 \pm 19.08$ (Table 2). A total of $166.98 \pm 20.15$ and $173.34 \pm 18.09$ were the total professionalism scores of male and female study participants, respectively, with no statistically significant $(P=0.61)$ differences (Table 3 ). Elements of professionalism showed no statistically significant differences between male and female research respondents except for responsibility component with statistically significant $(P=0.020)$ differences, and rest of the eight elements of professionalism had no statistically significant $(P>0.05)$ differences (Table 3 ). A total of $170.17 \pm 18.67$ and $171.49 \pm 19.49$ were the total professionalism scores of preclinical and clinical study participants, respectively, with no statistically significant $(P=0$. 694) differences (Table 4). There were no statistically significant $(P>0.05)$ differences observed between preclinical and clinical phases in the nine core elements of professionalism (Table 4). A total of $170.33 \pm 18.69,170.03 \pm 18.94,171.10 \pm 26.38$, 171.31 \pm 16.46 , and $171.93 \pm 16.67$ were the total professionalism scores of Year I, Year II, Year III, Year IV, and Year V of
Table I Sociodemographic profiles of the study participants $(n=144)$

\begin{tabular}{|c|c|c|}
\hline Variable & $\mathbf{n}$ & $\%$ \\
\hline \multicolumn{3}{|l|}{ Sociodemographic characteristics } \\
\hline \multicolumn{3}{|l|}{ Sex } \\
\hline Male & 54 & 37.5 \\
\hline Female & 90 & 62.5 \\
\hline \multicolumn{3}{|l|}{ Race } \\
\hline Malay & 94 & 65.3 \\
\hline Chinese & 25 & 17.4 \\
\hline Indian & 24 & 16.7 \\
\hline Others & 1 & 0.7 \\
\hline \multicolumn{3}{|l|}{ Religion } \\
\hline Islam & 95 & 66.0 \\
\hline Buddha & 21 & 14.6 \\
\hline Hindu & 18 & 12.5 \\
\hline Christian & 7 & 4.9 \\
\hline Others & 3 & 2.1 \\
\hline Educational characteristics & $\mathbf{n}$ & $\%$ \\
\hline \multicolumn{3}{|l|}{ Years of study } \\
\hline Year I & 29 & 20.1 \\
\hline Year II & 33 & 22.9 \\
\hline Year III & 24 & 16.7 \\
\hline Year IV & 27 & 18.8 \\
\hline Year V & 31 & 21.5 \\
\hline \multicolumn{3}{|l|}{ Phases of study } \\
\hline Phase I (basic sciences) & 62 & 43.0 \\
\hline Phase II (clinical medicine) & 82 & 57.0 \\
\hline \multicolumn{3}{|l|}{ Grades of the last examination } \\
\hline A & 7 & 4.9 \\
\hline $\mathrm{B}+$ & 6 & 4.2 \\
\hline B & 16 & 11.1 \\
\hline $\mathrm{C}+$ & 7 & 4.9 \\
\hline C & 12 & 8.3 \\
\hline Passed & 9 & 6.3 \\
\hline Not stated & 87 & 60.4 \\
\hline
\end{tabular}

study participants, respectively, with no statistically significant $(P=0.996)$ differences (Table 5). Similarly, there were no statistically significant $(P>0.05)$ differences observed in any of the nine components of professionalism (Table 5). A total of $168.50 \pm 31.21,180.00 \pm 19.64,176.69 \pm 21.02,168.17 \pm 10.17$, $173.08 \pm 21.62,151.71 \pm 29.4$, and $170.83 \pm 16.01$ were the total professionalism scores of study participants who obtained grades $\mathrm{A}, \mathrm{B}+, \mathrm{B}, \mathrm{C}+, \mathrm{C}$, passed, and not stated in the last examination, respectively, with no statistically significant $(P=0.11)$ differences (Table 6). Based on the mean scores, comparison respectful $(P=0.05)$ and compassion $(P=0.04)$ showed statistically significant differences, and seven of the nine core elements of professionalism showed no statistically significant $(P>0.05)$ differences (Table 6).

The last part of the questionnaire contains four open-ended questions. The first question was "what do you mean by professionalism", and 48\% (69), 15\% (22), 15\% (22), and 22\% (31) of the study participants thought that the answer was a 


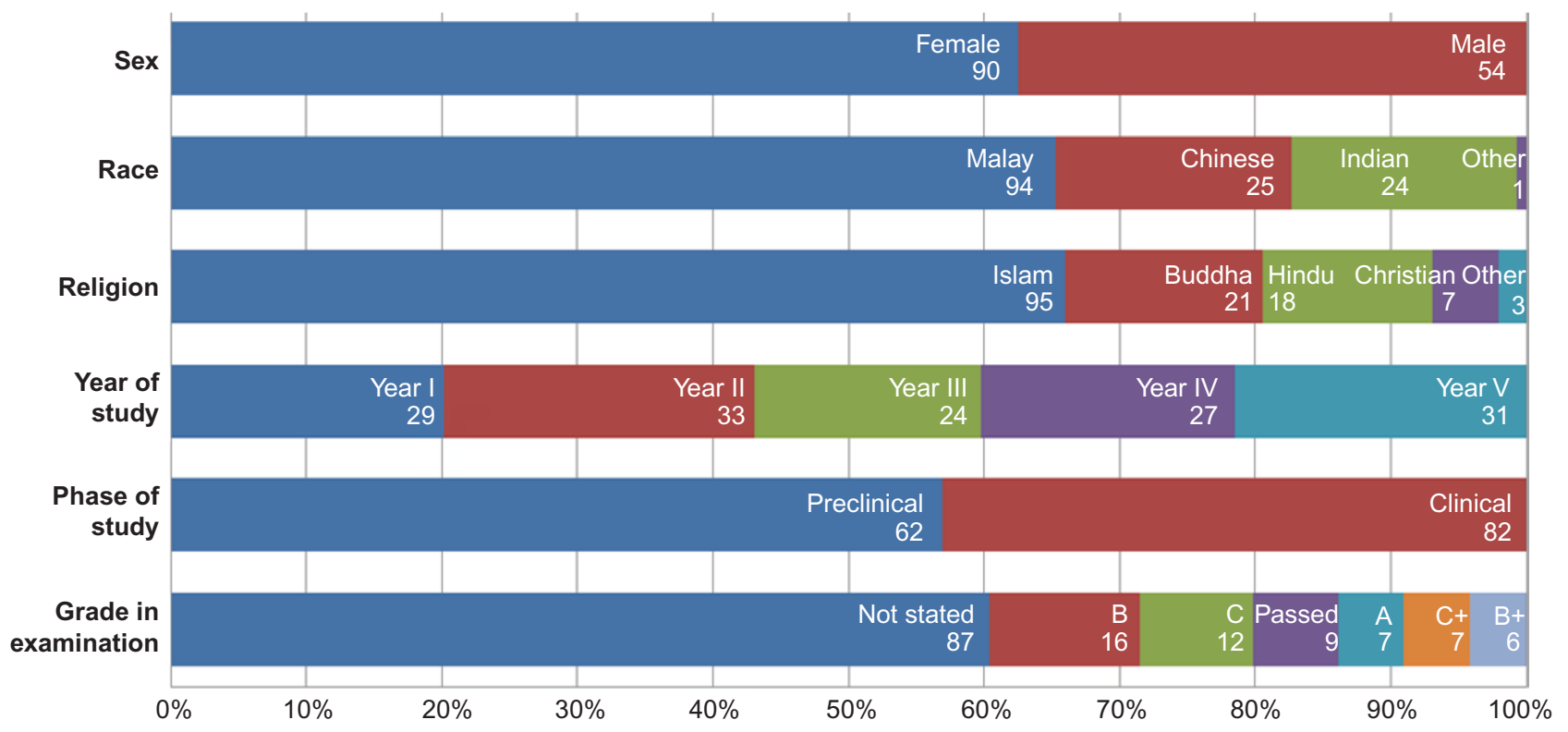

Figure I Profiles of participants of professionalism questionnaire by medical students of UniSZA ( $N=144)$.

Abbreviation: UniSZA, Universiti Sultan Zainal Abidin.

Table 2 Mean item scores of professionalism of medical students of UniSZA $(n=\mid 44)$

\begin{tabular}{|c|c|c|}
\hline Professionalism characteristics & Item & Mean (SD) \\
\hline \multirow[t]{6}{*}{ Honesty } & I am fair to people & $3.79(0.72)$ \\
\hline & I am straightforward to people & $3.64(0.93)$ \\
\hline & I do not tell lies & $3.35(1.06)$ \\
\hline & I am truthful to people & $3.79(0.72)$ \\
\hline & I keep my promise & $3.94(0.83)$ \\
\hline & I admit mistakes & $3.95(0.70)$ \\
\hline Total & & $22.44(3.43)$ \\
\hline \multirow[t]{5}{*}{ Accountability } & I am punctual & $3.60(0.92)$ \\
\hline & I carry out my duty well & $3.81(0.74)$ \\
\hline & I inform supervisor/team when mistakes occur & $3.85(0.79)$ \\
\hline & I am a good leader & $3.40(0.81)$ \\
\hline & I complete assignments on time & $3.74(0.78)$ \\
\hline Total & & $18.38(2.95)$ \\
\hline \multirow[t]{4}{*}{ Confidentiality } & I can keep secret accordingly & $4.13(0.77)$ \\
\hline & I do not talk private issues of other people & $3.81(0.92)$ \\
\hline & I don't gossip about a person's secret & $3.69(1.94)$ \\
\hline & I act in accordance with known guidance & $3.92(0.68)$ \\
\hline Total & & $15.56(3.01)$ \\
\hline \multirow[t]{6}{*}{ Respectful } & I greet my lecturer & $4.20(0.67)$ \\
\hline & I always talk to senior, lecturer in polite tone & $4.20(0.64)$ \\
\hline & I respect a person's decision & $4.17(0.60)$ \\
\hline & I pay attention when the lecturer is giving lectures & $3.76(0.84)$ \\
\hline & I can tolerate diversity & $4.08(0.69)$ \\
\hline & I establish rapport with team members & $4.03(0.65)$ \\
\hline Total & & $24.45(3.11)$ \\
\hline \multirow[t]{6}{*}{ Responsibility } & I try my best to do the task assigned & $4.22(0.60)$ \\
\hline & I fix the mistake that I commit & $4.04(0.55)$ \\
\hline & I prepare well before classes & $2.97(0.92)$ \\
\hline & I am reliable & $3.79(0.72)$ \\
\hline & I do not commit crime & $4.13(0.98)$ \\
\hline & I never reject task that was assigned to me if I am capable of & $3.99(0.69)$ \\
\hline Total & & $23.13(2.91)$ \\
\hline
\end{tabular}

(Continued) 
Table 2 (Continued)

\begin{tabular}{|c|c|c|}
\hline Professionalism characteristics & Item & Mean (SD) \\
\hline \multirow[t]{4}{*}{ Compassion } & I am considerate to other people & $4.02(0.60)$ \\
\hline & I always reflect what I have done & $3.96(0.62)$ \\
\hline & I always care about people & $4.39(0.43)$ \\
\hline & I am willing to help people in need & $4.15(0.7 I)$ \\
\hline Total & & I6.5। (4.85) \\
\hline \multirow[t]{5}{*}{ Communication } & I can communicate well orally & $3.74(0.78)$ \\
\hline & I can express my opinion as well & $3.65(0.80)$ \\
\hline & I can use body language well if someone doesn't understand my language & $3.83(0.70)$ \\
\hline & I can write well to the level of others understanding & $3.82(0.76)$ \\
\hline & I allow talking without interruption & $3.69(0.77)$ \\
\hline Total & & $18.75(3.10)$ \\
\hline \multirow[t]{6}{*}{ Maturity } & I think before making a decision & $4.01(0.66)$ \\
\hline & I can manage relationships with others as well & $3.90(0.75)$ \\
\hline & I am able to think critically & $3.85(0.68)$ \\
\hline & I do my job in an organized method & $3.81(0.77)$ \\
\hline & I can recognize and correct my mistake & $3.97(0.6 \mathrm{I})$ \\
\hline & I am able to differentiate what is right and what is wrong & $4.23(0.61)$ \\
\hline Total & & $23.77(3.20)$ \\
\hline \multirow[t]{2}{*}{ Self-directed learning } & I am able to learn independently & $3.90(0.88)$ \\
\hline & I always try to improve myself & $4.24(0.74)$ \\
\hline \multirow[t]{2}{*}{ Total } & & $8.13(1.42)$ \\
\hline & Grand total score & $170.92(19.08)$ \\
\hline
\end{tabular}

Abbreviation: UniSZA, Universiti Sultan Zainal Abidin.

Table 3 Comparison mean score of professionalism by medical students of UniSZA according to sex $(n=\mid 44)$

\begin{tabular}{|c|c|c|c|c|}
\hline \multirow[t]{2}{*}{ Professionalism characteristics } & \multicolumn{2}{|l|}{ Mean (SD) } & \multirow[t]{2}{*}{$t$ statistic $(d f)$} & \multirow[t]{2}{*}{$P$-value ${ }^{a}$} \\
\hline & Male $(n=54)$ & Female $(n=90)$ & & \\
\hline Honesty & $22.39(3.69)$ & $22.33(3.26)$ & $-0.055(138)$ & 0.956 \\
\hline Accountability & $17.82(2.70)$ & $18.69(3.12)$ & $-1.8 I I(\mid 4 I)$ & 0.72 \\
\hline Confidentiality & $|5.3|(2.28)$ & $|5.6|(3.42)$ & $-0.620(142)$ & 0.531 \\
\hline Respectful & $24.00(3.09)$ & $24.76(3.14)$ & $-1.316(140)$ & 0.190 \\
\hline Responsibility & $22.35(2.99)$ & $23.58(2.82)$ & $-2.362(|4|)$ & 0.020 \\
\hline Compassion & $15.76(2.64)$ & $16.99(5.98)$ & $-1.525(142)$ & 0.130 \\
\hline Communication & $18.06(3.28)$ & $19.10(3.00)$ & $-1.935(\mid 4 I)$ & 0.055 \\
\hline Maturity & $23.39(3.66)$ & $24.04(2.85)$ & $-1.160(140)$ & 0.248 \\
\hline Self-directed learning & $7.88(1.29)$ & $8.24(\mathrm{I} .5 \mathrm{I})$ & $-1.730(142)$ & 0.086 \\
\hline Grand total score & $166.98(20.15)$ & I73.34 (I8.09) & $-1.891(132)$ & 0.61 \\
\hline
\end{tabular}

Notes: andependent $t$-test. Bold text denotes statistical significance.

Abbreviation: UniSZA, Universiti Sultan Zainal Abidin.

Table 4 Comparison of mean score of professionalism by medical students of UniSZA according to educational phase $(n=\mid 44)$

\begin{tabular}{|c|c|c|c|c|}
\hline \multirow{2}{*}{$\begin{array}{l}\text { Professionalism } \\
\text { characteristics }\end{array}$} & \multicolumn{2}{|l|}{ Mean (SD) } & \multirow[t]{2}{*}{$t$ statistic $(d f)$} & \multirow[t]{2}{*}{$P$-value } \\
\hline & Preclinical $(n=62)$ & Clinical $(n=82)$ & & \\
\hline Honesty & $22.67(3.52)$ & $22.11(3.34)$ & $0.916(138)$ & 0.361 \\
\hline Accountability & $18.02(2.48)$ & $18.62(3.31)$ & $-1.302(140.70)$ & 0.195 \\
\hline Confidentiality & $15.44(3.47)$ & $15.54(2.67)$ & $-0.304(142)$ & 0.762 \\
\hline Respectful & $24.19(3.25)$ & $24.68(3.04)$ & $-1.196(140)$ & 0.234 \\
\hline Responsibility & $23.33(2.82)$ & $23.14(3.04)$ & $-0.419(141)$ & 0.676 \\
\hline Compassion & $16.36(2.50)$ & $16.64(6.29)$ & $-0.34 I(142)$ & 0.733 \\
\hline Communication & $18.36(3.39)$ & $18.97(2.93)$ & $-1.350(14 I)$ & 0.179 \\
\hline Maturity & $23.01(3.42)$ & $23.70(3.01)$ & $0.103(140)$ & 0.918 \\
\hline Self-directed learning & $8.15(1.4 I)$ & $8.12(1.45)$ & $0.097(142)$ & 0.923 \\
\hline Grand total score & $170.17(18.67)$ & 171.49 (19.49) & $-0.394(132)$ & 0.694 \\
\hline
\end{tabular}

Note: andependent $t$-test.

Abbreviation: UniSZA, Universiti Sultan Zainal Abidin. 
Table 5 Comparison mean scores of professionalism of medical students of UniSZA according to educational phase ( $n=\mid 44)$

\begin{tabular}{|c|c|c|c|c|c|c|c|}
\hline \multirow{2}{*}{$\begin{array}{l}\text { Professionalism } \\
\text { characteristics }\end{array}$} & \multicolumn{5}{|l|}{ Mean (SD) } & \multirow[t]{2}{*}{$t$ statistic $(d f)$} & \multirow[t]{2}{*}{$P$-value } \\
\hline & Year I & Year II & Year III & Year IV & Year V & & \\
\hline Honesty ${ }^{\mathrm{a}}$ & $22.70(3.26)$ & $22.65(3.79)$ & $21.57(4.57)$ & $21.96(2.37)$ & $22.62(3.08)$ & $3.093(4)$ & 0.542 \\
\hline Accountability & $17.70(2.49)$ & $18.29(2.48)$ & $19.24(4.13)$ & $18.23(2.85)$ & I8.52 (3.07) & $4.532(4)$ & 0.339 \\
\hline Confidentiality ${ }^{a}$ & $15.56(4.48)$ & $15.35(2.33)$ & $15.57(3.80)$ & $15.62(1.98)$ & $15.45(2.29)$ & $2.051(4)$ & 0.726 \\
\hline Respectful ${ }^{b}$ & $23.96(3.49)$ & $24.39(3.07)$ & $25.29(3.84)$ & $24.42(2.96)$ & $24.48(2.47)$ & $0.85 I(4,137)$ & 0.495 \\
\hline Responsibility ${ }^{b}$ & $23.19(3.09)$ & $22.97(2.61)$ & $23.29(4.05)$ & $22.92(2.5 I)$ & $23.24(2.63)$ & $0.244(4,138)$ & 0.913 \\
\hline Compassion $^{\mathrm{b}}$ & $16.41(2.39)$ & $16.32(2.63)$ & $15.76(2.39)$ & $17.88(10.44)$ & $16.17(1.58)$ & $0.699(4,139)$ & 0.594 \\
\hline Communication $^{\mathrm{b}}$ & $18.59(3.20)$ & $18.16(3.58)$ & $19.29(3.94)$ & $18.50(1.98)$ & $19.17(2.84)$ & $0.911(4,138)$ & 0.460 \\
\hline Maturity & $23.93(3.58)$ & $23.90(3.33)$ & $23.24(4.00)$ & $23.69(2.45)$ & $24.03(2.69)$ & $0.048(4,137)$ & 0.996 \\
\hline Self-directed learning ${ }^{\mathrm{b}}$ & $8.30(1.38)$ & $8.00(1.44)$ & $7.86(2.35)$ & $8.08(1.02)$ & $8.24(0.91)$ & $0.185(4,139)$ & 0.946 \\
\hline Total score ${ }^{b}$ & $170.33(18.69)$ & $170.03(18.94)$ & $171.10(26.38)$ & $|7| .3 \mid(\mid 6.46)$ & $171.93(16.67)$ & $0.045(4,129)$ & 0.996 \\
\hline
\end{tabular}

Notes: ${ }^{\mathrm{K}} \mathrm{Kruskal-Wallis}$ test. ${ }^{\mathrm{b}} \mathrm{One}-\mathrm{way}$ ANOVA.

Abbreviations: ANOVA, analysis of variance; UniSZA, Universiti Sultan Zainal Abidin.

Table 6 Comparison mean scores of professionalism of medical students of UniSZA according to grade of the examination result $(n=144)$

\begin{tabular}{|c|c|c|c|c|c|c|c|c|c|}
\hline \multirow{2}{*}{$\begin{array}{l}\text { Professionalism } \\
\text { characteristics }\end{array}$} & \multicolumn{7}{|l|}{ Mean (SD) } & \multirow{2}{*}{$\begin{array}{l}t \text { statistic } \\
\text { (df) }\end{array}$} & \multirow[t]{2}{*}{$P$-value } \\
\hline & A & B+ & B & $\mathrm{C}+$ & C & Passed & Not stated & & \\
\hline Honesty ${ }^{\mathrm{b}}$ & $20.67(7.28)$ & $23.33(4.68)$ & $22.88(3.40)$ & $22.17(2.40)$ & $22.75(3.48)$ & |9.7| (5.35) & $22.48(2.73)$ & $0.785(6,133)$ & 0.58 \\
\hline Accountability $^{\mathrm{b}}$ & $18.83(1.60)$ & $20.67(3.83)$ & $19.50(3.35)$ & $18.00(2.28)$ & $17.08(2.54)$ & $17.14(4.18)$ & $18.25(2.83)$ & $1.678(6,136)$ & 1.13 \\
\hline Confidentiality ${ }^{b}$ & $14.00(1.55)$ & $15.67(3.61)$ & $14.94(3.17)$ & $15.17(0.98)$ & $15.83(2.25)$ & $13.43(3.31)$ & $15.86(3.17)$ & $1.307(6,137)$ & 0.26 \\
\hline Respectful ${ }^{b}$ & $25.00(2.83)$ & $25.83(5.00)$ & $26.19(3.35)$ & $23.17(2.14)$ & $23.83(3.66)$ & $22.14(3.85)$ & $23.38(2.74)$ & $2.163(6,135)$ & 0.05 \\
\hline Responsibility & $23.33(3.50)$ & $24.17(3.31)$ & $24.13(3.36)$ & $23.17(0.98)$ & $23.42(1.98)$ & $20.86(4.53)$ & $22.96(2.80)$ & I.I $50(6,136)$ & 0.34 \\
\hline Compassion $^{\mathrm{a}}$ & 15.17 (4.67) & I $5.67(0.52)$ & $17.00(2.39)$ & $16.17(2.14)$ & $20.83(15.00)$ & I3.57 (3.26) & $16.23(1.80)$ & II.098 (6) & 0.04 \\
\hline Communication $^{\mathrm{b}}$ & $17.67(7.03)$ & $21.33(3.44)$ & $19.75(3.42)$ & $19.00(1.26)$ & $18.25(2.80)$ & $16.86(2.79)$ & $18.59(2.72)$ & I. $454(6,136)$ & 0.20 \\
\hline Maturity ${ }^{b}$ & $25.00(5.40)$ & $24.50(2.8 I)$ & 23.69 (3.94) & $23.17(2.32)$ & $23.67(3.60)$ & $21.00(4.90)$ & $23.98(2.61)$ & I.77| $(6,135)$ & 0.11 \\
\hline $\begin{array}{l}\text { Self-directed } \\
\text { learning }^{\mathrm{a}}\end{array}$ & $8.83(1.33)$ & $8.83(0.98)$ & $8.63(1.36)$ & $8.17(1.33)$ & $7.42(1.24)$ & $7.00(1.53)$ & $8.09(1.45)$ & $12.918(6)$ & 0.09 \\
\hline Total score ${ }^{b}$ & $168.50(3|.2|)$ & 180.00 & 176.69 & $168.17(10.17)$ & 173.08 & $|5| .7 \mid(29.04)$ & $170.83(16.01)$ & $1.776(6,127)$ & 0.11 \\
\hline
\end{tabular}

Notes: ${ }^{a}$ Kruskal-Wallis test. ${ }^{b}$ One-way ANOVA. Bold text denotes statistical significance.

Abbreviations: ANOVA, analysis of variance; UniSZA, Universiti Sultan Zainal Abidin.

confident approach profession, skill, others, and not responded, respectively. The second question was "how professionalism should be taught", and 33\% (48), 20\% (28), 18\% (26), 10\% (15), and $19 \%$ (27) of the study participants thought that the answer was an experience, role model, formal education, others, and not responded, respectively. The third question was "how do you learn professionalism", and 27\% (38), 22\% (32), $8 \%$ (12), $26 \%$ (38), and $17 \%$ (24) of the study participants thought that the answer was a role model, experiences, formal education, others, and not responded, respectively. The fourth question was "how the professionalism should be assessed", and $24 \%$ (35), $13 \%$ (19), 3\% (5), 38\% (55), and $21 \%$ (30) of the study participants thought that the answer was attitude and job, performance feedback and self-reflection, formal education, others, and not responded, respectively.

\section{Discussion}

Medical doctors share a common professional standard and responsibility throughout the world, although there are enormous differences in culture and health care backgrounds. ${ }^{105}$
However, globally, researchers, medical educators, and all concerns became highly apprehensive about medical professionalism because of many changes in health care in last few decades. ${ }^{106-109}$ Multiple research internationally indicated that primarily, of advanced world, there have been many new issues are arising, those are challenging professionalism among medical doctors. ${ }^{105,110,111}$ Every branch of medical doctors is facing a breach of their professional behavior leading to a negative impact on the society. ${ }^{79}$ Therefore, internationally medical schools are giving much quality time and effort regarding teaching and curriculum design in order to generate educational atmospheres that will ensure professionalism. ${ }^{110,112}$ Consequently, a group of researchers demanded that education regarding professionalism should start immediately as a developmental process. ${ }^{113}$ Professionalism develops convention between the social order and physician. Hence, it is firmly anticipated that physicians will apply their professional knowledge and skill that will eventually benefit and give relief to patients. ${ }^{10}$ Core values of professionalism have been evolved through the commonality of disease and healing process. 
Disease process and healing share same pain and joy, whether a community is white, brown, or black. ${ }^{105}$ The response rate of the students for this study was $87 \%$, which is very similar to that of a Danish study. ${ }^{114}$ In this study, female medical students were outnumbered by their male counterparts. This finding is analogous to that of a number of studies in many other countries. ${ }^{115-118}$ Malaysia is mainly Malay predominant and a Muslim country. Therefore, the majority of the study population were Malay and Muslim (Table 1 and Figure 1).

There were no significant $(P=0.61)$ differences between sexes of the mean scores of professionalism, although these came from different socioeconomic, educational, religious, and racial backgrounds (Table 3 ). In responsibility component, female students scored significantly $(P=0.02)$ higher than their male counterpart (Table 3 ). This particular finding can be explained by the fact that females have more responsibility and empathy sense than males. ${ }^{119,120}$ Moreover, the principal author started working in Malaysia in his 50s with 26 years of teaching experience and has personal feelings that Malaysian women have a higher responsibility sense than men. He had conducted a quick text message survey among local and expatriate colleagues, and all of them possess similar view that generally Malaysian women, are more responsible than men. Scores $(166.98 \pm 20.15)$ in this study were somewhat lower among males than those of previous studies of Malaysia $(172.31 \pm 13.39,172.58 \pm 2.53 \text {, and } 173.50)^{91,93,94}$ and

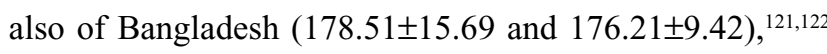
but scores of female medical students (173.34 \pm 18.09$)$ in this study were almost similar to earlier Malaysian studies $(174.58 \pm 17.95,174.17 \pm 2.16 \text {, and } 172.83)^{91,93,94}$ but lower than Bangladeshi studies (175.33 \pm 8.99 and $177.90 \pm 15.70) .{ }^{121,122}$ It is quite tough to explain why female medical students scored higher, but in this study, male participants were almost half of females. Consequently, it may influence because the disproportion between sexes may affect the result. Moreover, a similar observation was also noticed in a number of studies where male students had scored lower than their female counterpart. ${ }^{91,94,121}$ Nevertheless, in two other studies, male students had better scores than female students. ${ }^{93,122}$ A number of studies from modern world claimed that the core values of professionalism vary significantly with sex, year of study, and social, cultural, and educational environments. ${ }^{123,124}$ Similarly, when compared between preclinical and clinical phases, there was no statistically $(P=0.694)$ significant difference, although in this study, findings of preclinical (170.17 \pm 18.67$)$ students were lower than the clinical medical (171.49 \pm 19.49$)$ students (Table 4). This can be explained as with maturity and seniority, the sense of professionalism improved. Again, in this study, findings were lower than earlier studies (175.56 \pm 16.85 , $175.63 \pm 2.46,175.73 \pm 9.14$, and $179.18 \pm 14.51$ ) of Malaysia and Bangladesh both in respect of preclinical and clinical students. ${ }^{91,93,121,122}$ Medical students of UniSZA scored almost similar, and there were no statistically $(P=0.996)$ significant differences observed when compared between all 5 years (Table 5). Multiple studies reported that students' assertiveness headed for professionalism has a tendency to decline for the period of the years of training. ${ }^{125,126}$ The current findings were not on the same line rather increases with the year of study, although with no statistically $(P>0.05)$ significant differences observed. In the same way, medical students of UniSZA scored almost similar, and there were no statistically $(P=0.11)$ significant differences observed when compared with their grades, obtained in the last examination (Table 6).

Overall scores have tended to be lower down from earlier studies; this is again tough to explain. This may be due to time as those studies were conducted 3-6 years before. Therefore, medical students' attitude toward all core issues of professionalism has changed. Nevertheless, scores almost similar to those of this study of all core issues of professionalism between different sexes, years of study, phases of study, and grades of respondents may denote a congenial, shared educational setting is working in this University. Intradepartmental and interdepartmental teamwork, livelihood, and mutual respect are very much needed for promoting the educational development rather than the competitive insolence. ${ }^{127}$ Among the present study respondents, $48 \%$ and $22 \%$ thought that professionalism resembles positive attitudes toward the profession and skill, respectively (Table 7 and Figure 2). These data have similarity with earlier studies ${ }^{76,94,124}$ but lower than some other studies. ${ }^{91,94,121}$ Researchers recognized that professionalism is easy to identify but exceedingly challenging to define and poorly understood. ${ }^{76,128}$ This is the place where faculty member must get in to make a rich understanding and prepare medical students to exercise on fundamental concerns of humanistic characteristics of professionalism. There should be vibrant harmony among the teachers in the development of professionalism among their students. ${ }^{125}$ In the research participants, $33 \%$ and $19 \%$ thinks that professionalism should be taught with experience and role model, respectively. These findings were more or less similar to earlier studies. ${ }^{91,94,121,122}$ Even though a number of studies concluded that professionalism is best learned from faculty role models, among the current study respondents, only one-fifth was in favor of role model. ${ }^{124,125,129-}$ ${ }^{131}$ The authors think that the respondents in this study were very young medical students who yet have not much exposed to real-life situation. Hence, due to lack of experience, they 
Table 7 Respondents' opinion through open-ended questions

\begin{tabular}{|c|c|c|c|c|c|c|c|}
\hline \multicolumn{2}{|c|}{$\begin{array}{l}\text { What do you mean by } \\
\text { professionalism? }\end{array}$} & \multicolumn{2}{|c|}{$\begin{array}{l}\text { How professionalism } \\
\text { should be taught? }\end{array}$} & \multicolumn{2}{|l|}{$\begin{array}{l}\text { How do you learn } \\
\text { professionalism? }\end{array}$} & \multicolumn{2}{|c|}{$\begin{array}{l}\text { How professionalism should } \\
\text { be assessed? }\end{array}$} \\
\hline Opinion & n (\%) & Opinion & n (\%) & Opinion & n (\%) & Opinion & n (\%) \\
\hline $\begin{array}{l}\text { Positive } \\
\text { approach to } \\
\text { profession }\end{array}$ & $69(47.9)$ & Experiences & $48(33.3)$ & Role model & $38(26.4)$ & $\begin{array}{l}\text { Attitude and job } \\
\text { performance }\end{array}$ & $35(24.3)$ \\
\hline Skill & $22(15.3)$ & Role model & $28(19.4)$ & Experiences & $32(22.2)$ & $\begin{array}{l}\text { Feedback and } \\
\text { self-reflection }\end{array}$ & $19(13.2)$ \\
\hline & & Formal education & $26(18.1)$ & Formal education & $12(8.33)$ & Formal examination & $5(3.47)$ \\
\hline Others & $22(15.3)$ & Others & $15(10.4)$ & Others & $38(26.4)$ & Others & $55(38.2)$ \\
\hline Not responded & $31(21.5)$ & Not responded & $27(18.8)$ & Not responded & $24(16.7)$ & Not responded & $30(20.8)$ \\
\hline
\end{tabular}

Note: Others, not relevant answers.

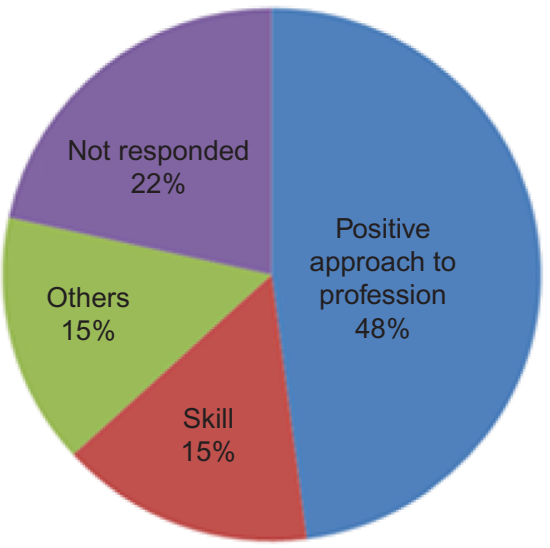

What do you mean by professionalism?

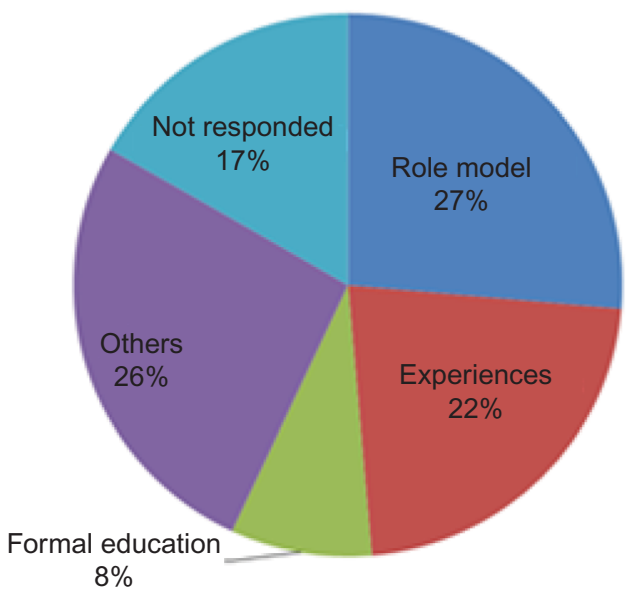

How do you learn professionalism?

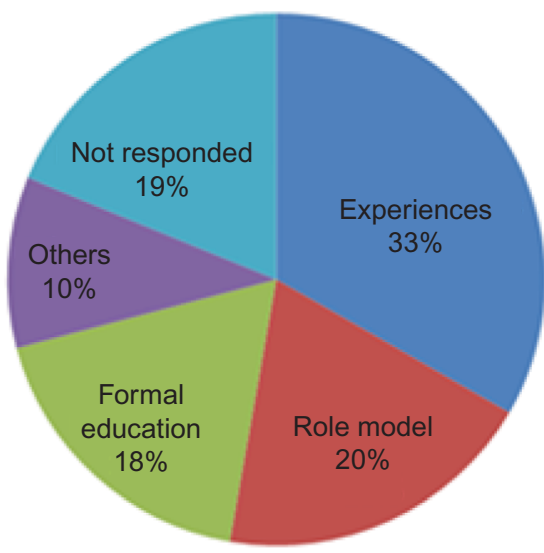

How professionalism should be taught?

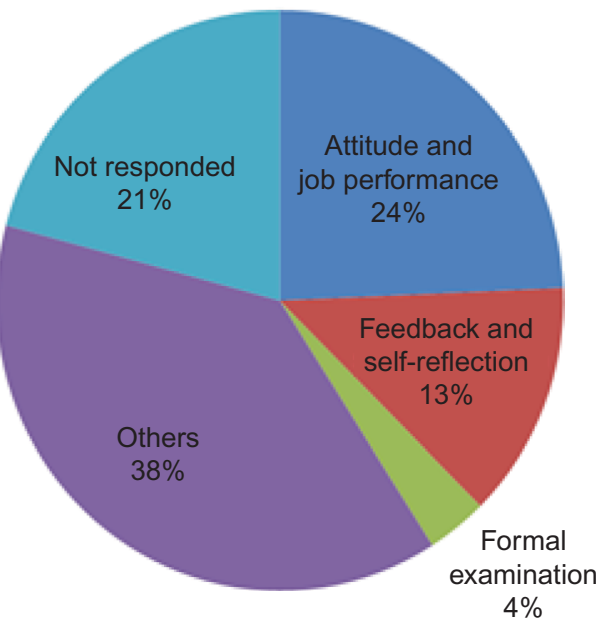

How professionalism should be assessed?

Figure 2 Respondents' opinion through open-ended questions.

were not aware of role model and professionalism. Moreover, $26 \%, 22 \%$, and $8 \%$ of the respondents in this study thought that professionalism was best learned through role model, experiences, and formal education, respectively. These findings were quite similar to earlier studies. ${ }^{94,121}$ Authors have an idea and believe that ordinary people anywhere in the world think that the role model is the hero and may be a war-hero or a football champion or a Nobel Laureate. As a result, authors have noticed that many parents have the desire deep in their heart and brain that their children will be like a role model. At the majority occasion, individuals also have the mind makeup to be famous like a role model. Then, the constructive role is 
one of the best ways to develop and protect professional values, attitudes, and behaviors among the medical students and house officers. ${ }^{132-134}$ Later, $24 \%, 13 \%$, and 3\% of the respondents in this study thought that professionalism assessed through attitude and job performance, feedback and self-reflection, and formal examination, respectively. The findings of this study were not consistent with the earlier studies. ${ }^{91,93,94,121,122,133,134}$ On an average, $22.58 \%$ and $19.45 \%$ of the study respondents answer four open-ended question "others" and "not responded", respectively. "Others" mean that answers were not very pertinent or cannot be categorized. It seems that medical students of UniSZA were quite hesitant and slothful to answer open-ended questions. These findings were also relatively comparable with a few preceding studies. ${ }^{121,122}$ However, these findings will hopefully contribute for the future development of Malaysian medical education and to the production of highquality rational prescribers.

\section{Limitation of the study}

This is a cross-sectional study with its own inherent limitations. Therefore, this is the only snapshot of perception of professionalism of medical students of UniSZA. The sample size was small, even though $50 \%$ of the total population (300) was randomly selected, as UniSZA is a new medical school of Malaysia with an intake of only 60 students per year. Therefore, the findings in this study will only serve as baseline data for further in-depth study.

\section{Conclusion}

This study found almost similar levels of familiarity with all nine core fundamental issues of professionalism, with no statistically $(P>0.05)$ significant differences between sexes, years of study, phases of study, and grades in the last examination. At least $21 \%$ of the respondents were oblivious about professionalism. The most important part to be noticed was that a good percentage of research respondents were naïve regarding role models and the development of professionalism. The education and improvement of professionalism have long been part of medical education and have had additional unique importance because of medical professionalism impinging on various new issues of health care policy and practice in the current century. Members of medical faculty should stress on the fundamental issues of professionalism, thus paving the way to the development of professionalism among medical doctors. Henceforth, researchers believe and expect that the country will produce more rational and holistic physicians for the ordinary people of Malaysia who will prescribe and treat patients on the basis of science.

\section{Acknowledgments}

Authors are much grateful to those medical students of UniSZA, who had participated in this study. The authors also like to extend their heartfelt thanks to all members of UniSZA Research Ethics Committee, especially to the Chairman Professor Dato' Dr Ahmad Zubaidi Bin Abdul Latif, MD (UKM), MMED(UM), FRCS (Edinburgh), of the ethical committee for his very kind cooperation. Professor Dato' Dr Ahmad Zubaidi Bin Abdul Latif currently holds the position of Vice-Chancellor of the UniSZA, Malaysia. This study obtained no funding. Principal author bears all cost where necessary to conduct the study because of his personal interests in this particular area.

\section{Disclosure}

The authors report no conflicts of interest in this work.

\section{References}

1. ACGME Core Competencies Definitions [webpage on the Internet]. Available from: http://www.gahec.org/CME/Liasions/0)ACGME\%20 Core\%20Competencies\%20Definitions.htm. Accessed April 14, 2016.

2. Mind Tools [webpage on the Internet]. Essential Skills for an Excellent Career. Available from: https://www.mindtools.com/pages/article/ professionalism.htm. Accessed February 1, 2016.

3. Medical Protection [webpage on the Internet]. Chapter 1: Medical Professionalism - What do we mean? 2015. Available from: http:// www.medicalprotection.org/uk/advice-booklets/professionalism-anmps-guide/chapter-1-medical-professionalism-what-do-we-mean. Accessed May 12, 2016.

4. Canadian Medical Association [webpage on the Internet]. Professionalism in Medicine. CMA Series of Health Care Discussion Papers; 2001. Available from: http://www.teamgrant.ca/M-THAC\%20Greatest $\% 20$ Hits/Bonus\%20Tracks/cma/professionalism.pdf. Accessed February 1, 2016.

5. Sit SW. Professionalism in vogue. Can Fam Physician. 2009;55(12): 1183.

6. AIBM Foundation [webpage on the Internet]. Advancing Medical Professionalism to Improve Health Care. 510 Walnut Street, Suite 1700, Philadelphia, PA 19106; 2015. Available from: http://www. abimfoundation.org/Professionalism/Medical-Professionalism.aspx. Accessed February 1, 2016.

7. Cruess RL, Cruess SR, Snell L [webpage on the Internet]. Teaching, Learning and Assessing Professionalism at the Post Graduate Level. Members of the FMEC PG Consortium; 2011. Available from: https:// www.afmc.ca/pdf/fmec/20_Cruess_Professionalism.pdf. Accessed February 1, 2016

8. Modi JN, Anshu, Gupta P, Singh T. Teaching and assessing professionalism in the Indian context. Indian Pediatr. 2014;51(11):881-888

9. Inui TS. A Flag in the Wind: Educating for Professionalism in Medicine. Washington, DC: Association of American Medical Colleges; 2003.

10. Epstein RM, Hundert EM. Defining and assessing professional competence. JAMA. 2002;287(2):226-235.

11. MacKenzie CR. Professionalism and medicine. HSS J. 2007;3(2): 222-227.

12. Stevens RA [webpage on the Internet]. Public roles for the medical profession in the United States: beyond theories of decline and fall. The Milbank Quarterly; 2001; 79(3). Available from: http://www.milbank.org/uploads/documents/featured-articles/html/Milbank_Quarterly_Vol-79_No-3_2001.htm. Accessed February 1, 2016. 
13. Cross J, MacGregor $\mathrm{H}$ [webpage on the Internet]. Who Are 'Informal Health Providers' and What Do They Do? Perspectives from Medical Anthropology. Future Health Systems Innovations for Equity. Institute of Development Studies at the University of Sussex, Brighton BN1 9RE, UK. Working Paper; 2009; 334. Available from: https://www. ids.ac.uk/files/dmfile/Wp334_Who_are_informal_health_providers_and_what_do_they_do.pdf. Accessed February 1, 2016.

14. Getz L [webpage on the Internet]. Sustainable and responsible preventive medicine. Conceptualizing ethical dilemmas arising from clinical implementation of advancing medical technology. Doctoral thesis. Department of Public Health and General Practice. Faculty of Medicine. Norwegian University of Science and Technology; 2006. Available from: http://ntnu.diva-portal.org/smash/get/diva2:125970/ FULLTEXT01. Accessed February 1, 2016.

15. Jakovljević M, Ostojić L. Professionalism in contemporary medicine: if it is an important academic issue, then surely it is a "hot" issue as well. Med Acad Mostariensia. 2013;1(1):6-17.

16. Jennings B, Baily MA, Bottrell M, Lynn J [webpage on the Internet]. Health Care Quality Improvement: Ethical and Regulatory Issues. The Hastings Center, Garrison, New York; 2007. Available from: http://www.thehastingscenter.org/uploadedFiles/Publications/ Special_Reports/Health\%20Care\%20Quality\%20Improvement.pdf. Accessed February 1, 2016.

17. Perry JE [webpage on the Internet]. The Ethical Costs Of Commercializing The Professions: First-Person Narratives From The Legal And Medical Trenches, 13 U. Pa. J.L. \& Soc. Change 169; 2010. Available from: http://scholarship.law.upenn.edu/jlasc/vol13/iss2/2. Accessed February 1, 2016.

18. Ficarrotta JC [webpage on the Internet]. The Leader's Imperative: Ethics, Integrity, and Responsibility. Purdue University Press e-books. Book 6; 2001. Available from: http://docs.lib.purdue.edu/purduepress_ebooks/6. Accessed February 1, 2016.

19. McLeod S [webpage on the Internet]. Nature vs Nurture in Psychology. Simple Psychology; 2007. Available from: http://www.simplypsychology.org/naturevsnurture.html. Accessed February 1, 2016.

20. Collier R. Professionalism: can it be taught? CMAJ. 2012;184(11): 1234-1236.

21. Kavas MV, Demirören M, Koşan AM, Karahan ST, Yalim NY [webpage on the Internet]. Turkish students' perceptions of professionalism at the beginning and at the end of medical education: a cross-sectional qualitative study. Medical education online. 2015;20. Available from: http://med-ed-online.net/index.php/meo/article/view/26614/pdf_18. Accessed February 1, 2016.

22. Dean J, Loh E, Coleman JJ. Pharmaceutical industry exposure in our hospitals: the final frontier. Med J Aust. 2016;204(1):20-22.

23. Medical Council of New Zealand [webpage on the Internet]. Doctors and Health Related Commercial Organizations; 2012. Available from: https://www.mcnz.org.nz/assets/News-and-Publications/Statements/ Respnsibilities-in-any-relationship.pdf. Accessed February 1, 2016.

24. May CD. Selling drugs by "educating" physicians. J Med Educ. 1961;36:1-23.

25. Gagnon MA, Lexchin J. The cost of pushing pills: a new estimate of pharmaceutical promotion expenditures in the United States. PLoS Med. 2008;5(1):e1.

26. Kornfield R, Donohue J, Berndt ER, Alexander GC. Promotion of prescription drugs to consumers and providers, 2001-2010. PLoS One. 2013;8(3):e55504.

27. IMS Health [homepage on the Internet]. Total US Promotional Spend by Type; 2011. Available from: http://www.imshealth.com/deployedfiles/ims/Global/Content/Corporate/Press\%20Room/Top-Line $\% 20$ Market\%20Data\%20\&\%20Trends/2011\%20Top-line\%20Market\%20 Data/Promo_Spend_By_Type.pdf. Accessed May 12, 2016.

28. Mack J. Pharma promotional spending in 2013 professional detailing, eDetailing, DTC advertising, professional meetings, journal advertising. Pharma Marketing News. 2014;13(5):1-7.
29. IMS Health [webpage on the Internet]. Global Pharmaceuticals Marketing Channel Reference; 2015. Available from: https://www. imshealth.com/files/web/Global/Market\%20Insights/IMSH\%20 GPMCR_2015_GlobalExtract.pdf. Accessed February 1, 2016.

30. Shashindran C. Push, promote or educate... musings of a pharmacologist on drug promotion. J Pharmacol Pharmacother. 2014;5(4):225-226.

31. Drake D, Uhlman M. Making Medicine, Making Money. Kansas City, MO: Andrews \& McMeel; 1993.

32. Randall $\mathrm{T}$. Kennedy hearings say no more free lunch - or much else - from drug firms. JAMA. 1991;265(4):440-442.

33. Fugh-Berman A, Ahari S. Following the script: how drug reps make friends and influence doctors. PLoS Med. 2007;4(4):e150.

34. Campbell EG, Rao SR, DesRoches CM, et al. Physician professionalism and changes in physician-industry relationships from 2004 to 2009. Arch Intern Med. 2010;170(20):1820-1826.

35. Wazana A. Physicians and the pharmaceutical industry. Is a gift ever just a gift? JAMA. 2000;283(3):373-380.

36. Lieb K, Scheurich A. Contact between doctors and the pharmaceutical industry, their perceptions, and the effects on prescribing habits. PLoS One. 2014;9(10):e110130.

37. Lieb K, Brandtönies S. A survey of German physicians in private practice about contacts with pharmaceutical sales representatives. Dtsch Arztebl Int. 2010;107(22):392-398.

38. Lexchin J. Interactions between physicians and the pharmaceutical industry: what does the literature say? CMAJ. 1993;149(10):1401.

39. Lodha R, Bhargava A. Financial incentives and the prescription of newer vaccines by doctors in India. Indian J Med Ethics. 2010;7(1):28-30.

40. Khan MM. Why physicians should not have any contact with pharmaceutical companies? J Pak Med Assoc. 2007;57(11):572-573.

41. Banerjee A. Industry and the medical profession: sleeping with the enemy. Med J DY Patil Univ. 2013;6(1):1-2.

42. Anand AC. Professional conferences, unprofessional conduct. Med $J$ Armed Forces India. 2011;67(1):2-6.

43. Chew LD, O'Young TS, Hazlet TK, Bradley KA, Maynard C, Lessler DS. A physician survey of the effect of drug sample availability on physicians' behavior. J Gen Intern Med. 2000;15(7):478-483.

44. Avorn J, Chen M, Hartley R. Scientific versus commercial sources of influence on the prescribing behavior of physicians. Am J Med. 1982;73(1):4-8.

45. Chren MM, Landefeld CS. Physicians' behavior and their interactions with drug companies. A controlled study of physicians who requested additions to a hospital drug formulary. JAMA. 1994;271(9): 684-689.

46. Orlowski JP, Wateska L. The effects of pharmaceutical firm enticements on physician prescribing patterns. There's no such thing as a free lunch. Chest. 1992;102(1):270-273.

47. Zipkin DA, Steinman MA. Interactions between pharmaceutical representatives and doctors in training: a thematic review. $J$ Gen Intern Med. 2005;20(8):777-786.

48. Manchanda P, Honka E. The effects and role of direct-to-physician marketing in the pharmaceutical industry: an integrative review. Yale $J$ Health Policy Law Ethics. 2005;5(2):785-822.

49. Dana J, Loewenstein G. A social science perspective on gifts to physicians from industry. JAMA. 2003;290(2):252-255.

50. Green MJ, Masters R, James B, Simmons B, Lehman E. Do gifts from the pharmaceutical industry affect trust in physicians? Fam Med. 2012;44(5):325.

51. Grande D, Shea JA, Armstrong K. Pharmaceutical industry gifts to physicians: patient beliefs and trust in physicians and the health care system. J Gen Intern Med. 2012;27(3):274-279.

52. Haque N, Haque M, Sultana R, et al. Teaching medical students the skills required to critically evaluate the drug information sources for rational prescribing - a report of an exercise on evaluation of prescribing information. Bangladesh J Physiol Pharmacol. 2005;21(1): $1-4$. 
53. Rothman DJ, McDonald WJ, Berkowitz CD, et al. Professional medical associations and their relationships with industry: a proposal for controlling conflict of interest. JAMA. 2009;301(13):1367-1372.

54. Mansfield PR, Lexchin J, Wen LS, et al. Educating health professionals about drug and device promotion: advocates' recommendations. PLoS Med. 2006;3(11):e451.

55. Montgomery BD, Mansfield PR, Spurling GK, Ward AM. Do advertisements for antihypertensive drugs in Australia promote quality prescribing? A cross-sectional study. BMC Public Health. 2008;8(1):167.

56. Ziegler MG, Lew $P$, Singer BC. The accuracy of drug information from pharmaceutical sales representatives. JAMA. 1995;273(16):1296-1298.

57. Hemminki E. Content analysis of drug-detailing by pharmaceutical representatives. Med Educ. 1977;11(3):210-215.

58. Abubakar AR, Sheikh SA, Haque M. Drug promotional literatures: educative or misleading for young medical graduates and students? Natl J Physiol Pharm Pharmacol. 2015;5(4):318-322.

59. Institute of Medicine (US) Committee on Conflict of Interest in Medical Research, Education, and Practice; Lo B, Field MJ, editors [webpage on the Internet]. Conflict of Interest in Medical Research, Education, and Practice. Washington, DC: National Academies Press (US); 2009. 6, Conflicts of Interest and Medical Practice. Available from: http://www.ncbi.nlm.nih.gov/books/NBK22944/. Accessed February 1, 2016.

60. Chimonas S, Brennan TA, Rothman DJ. Physicians and drug representatives: exploring the dynamics of the relationship. J Gen Intern Med. 2007;22(2):184-190.

61. Thomas JM [webpage on the Internet]. Self-regulation and the relationship of physicians with the pharmaceutical industry. Virtual Mentor. 2005;7(4). Available from: http://journalofethics.ama-assn org/2005/04/jdsc1-0504.html. Accessed February 1, 2016.

62. Guðmundsson S. Doctors and drug companies: the beauty and the beast? Acta Ophthalmol Scand. 2005;83(4):407-408.

63. Henry D. Doctors and drug companies: still cozy after all these years. PLoS Med. 2010;7(11):e1000359.

64. Hafemeister TL, Bryan SP [webpage on the Internet]. Beware those bearing gifts: physicians' fiduciary duty to avoid pharmaceutical marketing. University of Kansas Law Review. 2009;57(3). Available from: http://papers.ssrn.com/sol3/papers.cfm?abstract_id=1458582. Accessed February 1, 2016.

65. Grup DE. Ethics in drug industry relations. Opinion poll of family physicians in Catalonia. Aten Primaria. 2004;34(1):6-12.

66. Brody H. The company we keep: why physicians should refuse to see pharmaceutical representatives. Ann Fam Med. 2005;3(1):82-85.

67. Diep F [webpage on the Internet]. Getting 'Em Early: Pharma Reps Give Gifts to Most Medical Students. Think of The Children! Or At Least, The Medical Students - and Their Future Patients. Science; 2013. Available from: http://www.popsci.com/science/article/2013-02/ getting-em-early-pharma-reps-give-gifts-most-medical-students. Accessed February 1, 2016.

68. Palmisano P, Edelstein J. Teaching drug promotion abuses to health profession students. J Med Educ. 1980;55(5):453-455.

69. Chattopadhyay S. Corruption in health care and medicine: why should physicians and bioethicists care and what should they do. Indian JMed Ethics. 2013;10(3):153-159.

70. The Free Dictionary [webpage on the Internet]. Medical ethics. Available from: http://medical-dictionary.thefreedictionary.com/ medical+ethics. Accessed May 12, 2016.

71. Parkar SR, Koli TF [webpage on the Internet]. Ethics in Dealing with Pharma Industries: 200-209. Available from: http://www.indianjpsychiatry.org/cpg/cpg2009/article4.pdf. Accessed February 1, 2016.

72. Tyson P [webpage on the Internet]. The Hippocratic Oath Today; 2001. Available from: http://www.pbs.org/wgbh/nova/body/hippocratic-oathtoday.html. Accessed February 1, 2016.

73. Huddle TS, ACGME. Viewpoint: teaching professionalism: is medical morality a competency? Acad Med. 2005;80(10):885-891.
74. Wynia MK, Latham SR, Kao AC, Berg JW, Emanuel LL. Medical professionalism in society. $N$ Engl J Med. 1999;341(21):1612-1616.

75. Wear D, Castellani B. The development of professionalism: curriculum matters. Acad Med. 2000;75(6):602-611.

76. Swick HM. Toward a normative definition of medical professionalism Acad Med. 2000;75(6):612-616.

77. Prabhu PP [webpage on the Internet]. Do you agree there is a decline in the ethical values in the field of medicine? If so, what are the contributing factors? Reserchgate; 2014. Available from: https://www researchgate.net/post/Do_you_agree_there_is_a_decline_in_the_ethical_values_in_the_field_of_medicineIf_so_what_are_the_contributing_factors. Accessed February 1, 2016.

78. Gottlieb M [webpage on the Internet]. Do you agree there is a decline in the ethical values in the field of medicine? If so, what are the contributing factors? Researchgate; 2014. Available from: https://www. researchgate.net/post/Do_you_agree_there_is_a_decline_in_the_ethical_values_in_the_field_of_medicineIf_so_what_are_the_contributing_factors. Accessed February 1, 2016.

79. Marlow AE. The professional decline of physicians in the era of managed care. N Engl J Public Policy. 1997;13(2):Article8.

80. Beauchamp G. The challenge of teaching professionalism. Ann Acad Med Singapore. 2004;33(6):697-705.

81. Atkinson $P$ [webpage on the Internet]. The Importance and Method of Teaching Children Morality. Available from: http://www.ourcivilisation.com/moral/moral3.htm. Accessed February 1, 2016.

82. Thornwood AW [webpage on the Internet]. Moral Values Need To Be Taught Early. The New York Times; 1992. Available from: http://www. nytimes.com/1992/12/20/nyregion/l-moral-values-need-to-be-taughtearly-710392.html. Accessed February 1, 2016.

83. Wilson RA [webpage on the Internet]. Fostering Goodness \& Caring: Promoting Moral Development of Young Children. The Professional Resource for Teachers and Parents; 2008. Available from: http://www.earlychildhoodnews.com/earlychildhood/article_view. aspx?ArticleID=565. Accessed February 1, 2016.

84. Carrese JA, Malek J, Watson K, et al. The essential role of medical ethics education in achieving professionalism: the Romanell Report. Acad Med. 2015;90(6):744-752.

85. Gondal GM. Role of teaching ethics in medical curriculum. Found Univ Med J. 2014;1(1):47-49.

86. Slomka J, Quill B, desVignes-Kendrick M, Lloyd LE. Professionalism and ethics in the public health curriculum. Public Health Rep. 2008;123(suppl 2):27-35.

87. Manson $\mathrm{H}$. The need for medical ethics education in family medicine training. Fam Med. 2008;40(9):658-664.

88. Horlick M, Masterton D, Kalet A [webpage on the Internet]. Learning skills of professionalism: a student-led professionalism curriculum. Medical Education Online; 2009: 11. Available from: http://meded-online.net/index.php/meo/article/viewFile/4615/4794/. Accessed February 1, 2016

89. Al-Eraky MM, Donkers J, Wajid G, Van Merrienboer JJ. Faculty development for learning and teaching of medical professionalism. Med Teach. 2015;37(sup1):S40-S46.

90. Stockley AJ, Forbes K. Medical professionalism in the formal curriculum: 5th year medical students' experiences. BMC Med Educ. 2014;14(1):259.

91. Salam A, Yousuf R, Islam MZ, et al. Professionalism of future medical professionals in Universiti Sultan Zainal Abidin, Malaysia. Bangladesh J Pharm. 2013;8(2):124-130.

92. Islam MZ, Salam A, Helali AM, et al. Comparative study of professionalism of future medical doctors between Malaysia and Bangladesh. J App Pharm Sci. 2014;4(4):66-71.

93. Salam A, Song CO, Mazlan NF, Hassin H, Lee LS, Abdullah MH A pilot study on professionalism of future medical professionals in Universiti Kebangsaan Malaysia (UKM) Medical Centre. Proced Soc Behav Sci. 2012a;60(3):534-540. 
94. Salam A, Song CO, Mazlan NF, Hassin H, Lee LS, Abdullah MH. Professionalism of future medical professionals in Universiti Kebangsaan Malaysia (UKM) Medical Centre. Int Med J. 2012b;19(3):224-228.

95. Ganasegeran K, Al-Dubai SA. Medical professionalism from a sociocultural perspective: evaluating medical residents communicative attitudes during the medical encounter in Malaysia. J Postgraduate Med. 2014;60(1):12-25.

96. Teoh SH. Continuing development in ethics and professionalism by Malaysian Medical Association. Jpn MedAssoc J. 2007;50(3):228-233.

97. Malaysian Qualifications Agency. Code of Practice for Program Accreditation. 2nd ed. Petaling Jaya, Selangor Darul Ehsan, Malaysia: Malaysian Qualifications Agency; 2008.

98. Malaysian Qualifications Agency. Code of Practice for Institutional Audit. 1st ed. Petaling Jaya, Selangor Darul Ehsan, Malaysia: Malaysian Qualifications Agency; 2008.

99. Rahman NI, Aziz AA, Zulkifli Z, et al. Perceptions of students in different phases of medical education of the educational environment: Universiti Sultan Zainal Abidin. Adv Med Educ Pract. 2015;6:211-222.

100. Ismail S, Salam A, Alattraqchi AG, et al. Evaluation of doctors' performance as facilitators in basic medical science lecture classes in a new Malaysian medical school. Adv Med Edu Pract. 2015;6:231-237.

101. Bhagat V, Haque M, Simbak NB, Jaalam K. Study on personality dimension negative emotionality affecting the academic achievement among Malaysian medical students studying in Malaysia and Overseas. Adv Med Edu Pract. 2016;7:341-346.

102. Creative Research System [webpage on the Internet]. Sample Size Calculator; 2012. Available from: http://www.surveysystem.com/ sscalc.htm. Accessed April 14, 2016.

103. Nunnally JC. Psychometric Theory. 2nd ed. New York, NY: McGrawHill; 1978.

104. Barman MP, Hazarika J, Kalita A. Reliability, and validity of Assamese version of EORTC QLQ-C30 questionnaire for studying the quality of life of cancer patients of Assam. World Appl Sci J. 2012;17(5): 672-678.

105. Arnold L, Stern DT. What is medical professionalism? In: Stern DT, editor. Measuring Medical Professionalism. New York, NY: Oxford University Press; 2006.

106. CalmanK. The profession ofmedicine. BMJ.1994;309(6962):1140-1143.

107. Cruess SR, Cruess RL. Professionalism must be taught. BMJ. 1997;315(7123):1674-1677.

108. Irvine D. The performance of doctors: the new professionalism. Lancet. 1999;353(9159):1174-1177.

109. Medical Professionalism Project. Medical Professionalism in the new millennium: a physician's charter. Lancet. 2002;359(9305):520-522.

110. Sullivan WM. Medicine under threat: professionalism and Professional identity. CMAJ. 2000;162(5):673-675.

111. Cruess SR, Cruess RL. Professionalism: a contract between medicine and society. CMAJ. 2000;162(5):668-669.

112. Chiu CH, Lu HY, Arrigo LG, Wei CJ, Tsai D. A professionalism survey of medical students in Taiwan. J Exp Clin Med. 2010;2(1):35-42.

113. Hultman CS, Connolly A, Halvorson EG, et al. Get on your boots: preparing fourth-year medical students for a career in surgery, using a focused curriculum to teach the competency of professionalism. J Surg Res. 2012;177(2):217-223.

114. Kongsved SM, Basnov M, Holm-Christensen K, Hjollund NH. Response rate and completeness of questionnaires: a randomized study of Internet versus paper-and-pencil versions. J Med Internet Res. 2007;9(3):e25.
115. Ismail S, Rahman NIA, Mohamad N, et al. Preference of teaching and learning methods in a new medical school of Malaysia. JAppl Pharm Sci. 2014;4(2):48-55.

116. Chen MK, Chevalier JA. Are women overinvesting in education? Evidence from the medical profession. J Hum Cap. 2012;6(2):124-149.

117. BBC [webpage on the Internet]. Women docs "weakening" medicine; 2004. Available from: http://news.bbc.co.uk/1/hi/health/3527184.stm. Accessed February 1, 2016.

118. Elston MA. Women and medicine: the future. Royal College of Physicians; 2009. Available from: https://www.rcr.ac.uk/sites/default/ files/RCP_Women_\%20in_\%20Medicine_\%20Report.pdf. Accessed February 1, 2016.

119. Sabbatini RME [webpage on the Internet]. Are There Differences between the Brains of Males and Females? Mind and Behavior; 1997. Available from: http://www.cerebromente.org.br/n11/mente/eisntein/ cerebro-homens.html. Accessed April 14, 2016.

120. Mulé CM [webpage on the Internet]. Why Women Are More Susceptible to Depression: An Explanation for Gender Differences. Rochester Institute of Technology; 2004. Available from: http://www. personalityresearch.org/papers/mule.html. Accessed April 14, 2016.

121. Salam A, Haque M, Islam MZ, et al. Comparative study of professionalism of future medical professionals among three private medical colleges in Bangladesh. Asian J Pharm Clin Res. 2013;6(3):170-179.

122. Salam A, Haque M, Helali AM, et al. Comparative study on professionalism of forthcoming medical doctors between two private medical colleges in Savar, Bangladesh. Int J Pharm Pharm Sci. 2013; 5(3):659-665.

123. Nath C, Schmidt R, Gunel E. Perceptions of professionalism vary, most with educational rank and age. J Dental Edu. 2006;70(8):825-834.

124. Cruess RL, Cruess SR, Steinert Y. Teaching Medical Professionalism. New York, NY: Cambridge University Press; 2009.

125. Brown D, Ferrill MJ. The taxonomy of professionalism: reframing the academic pursuit of professional development. Am J Pharm Educ. 2009;73(4):68.

126. Duke LJ, Kennedy K, McDuffie CH, Miller MS, Sheffield MC, Chisholm MA. Student attitudes, values and beliefs regarding professionalism. Am J Parm Educ. 2005;69(5):1. [Article 104].

127. Salam A, Ghafar AA, Latif HA, et al. Synchronous transnational collaborative learning: an interesting model of education to learn medicine in global perspectives. South East Asia J Public Health. 2011; 1(1):59-63.

128. Riley S, Kumar N. Teaching medical professionalism. Clin Med. 2012;12(1):9-11.

129. Brainard AH, Brislen HC. Viewpoint: learning, professionalism: a view from the trenches. Acad Med. 2007;82(11):1010-1014.

130. Hammer DP. Professional attitudes and behaviors: the" A's and B's" of professionalism. Am J Pharm Educ. 2000;64(4):455.

131. Kenny NP, Mann KV, MacLeod H. Role modeling in physicians' professional formation: reconsidering an essential, but untapped educational strategy. Acad Med. 2003;78(12):1203-1210.

132. Swick HM, Szenas P, Danoff D, Whitcomb ME. Teaching Professionalism in undergraduate medical education. JAMA. 1999;282(9):830-832.

133. Wear D. On white coats and professional development: the formal and the hidden curricula. Ann Intern Med. 1998;129(9):734-737.

134. Salam A, Siraj HH, Mohamad N, Das S, Yousuf R. Bedside teaching in undergraduate medical education: issues, strategies and new models for better preparation of new generation doctors. Iran J Med Sci. 2011;36(1):1-6. 


\section{Supplementary materials}

Date of data collection:

Dear respondents,

This evaluation form seeks information about your experience on professionalism. You don't need to write name or metric number that will reveal your identification. The information will be used just for research purpose. If you agree to participate in this study, just mention your sociodemographic attributes like year of study, gender and age as stated below and we expect your honest response.

A) Demographical questions

(Please round and give $\mathrm{X}$ in appropriate place)

1. Sex: Male/Female

2. Date of Birth and Age:

3. Race:

4. Religion:

5. State:

6. Year of Study: $1^{\text {st }} / 2^{\text {nd }} / 3^{\text {rd }} / 4^{\text {th }} / 5^{\text {th }}$. Grade in Last Professional/Semester Exam (If in Clinical Year Professional and Semester if Preclinical):

B) Please indicate your response by ENCIRCLING 1=SD (Strongly Disagree); 2=D (Disagree); 3=U (Unsure); 4=A (Agree); 5=SA (Strongly Agree) which most closely corresponds to your view against each statement.

\begin{tabular}{|c|c|c|c|c|c|}
\hline Statement & SD & D & $\mathbf{U}$ & A & SA \\
\hline \multicolumn{6}{|l|}{ 1. Honesty } \\
\hline 1. I am fair to people & 1 & 2 & 3 & 4 & 5 \\
\hline 2. I am straightforward to people & 1 & 2 & 3 & 4 & 5 \\
\hline 3. I do not tell lies & 1 & 2 & 3 & 4 & 5 \\
\hline 4. I am truthful to people & 1 & 2 & 3 & 4 & 5 \\
\hline 5. I keep my promise & 1 & 2 & 3 & 4 & 5 \\
\hline 6. I admit mistake & 1 & 2 & 3 & 4 & 5 \\
\hline \multicolumn{6}{|l|}{ 2. Accountability } \\
\hline 1. I am punctual & 1 & 2 & 3 & 4 & 5 \\
\hline 2. I carry out my duty well & 1 & 2 & 3 & 4 & 5 \\
\hline 3. I inform supervisor/team when mistakes occur & 1 & 2 & 3 & 4 & 5 \\
\hline 4. I am a good leader & 1 & 2 & 3 & 4 & 5 \\
\hline 5. I complete assignment on time & 1 & 2 & 3 & 4 & 5 \\
\hline \multicolumn{6}{|l|}{ 3. Confidentiality } \\
\hline 1. I can keep secret accordingly & 1 & 2 & 3 & 4 & 5 \\
\hline 2. I do not talk private issues of other people & 1 & 2 & 3 & 4 & 5 \\
\hline 3. I don't gossip about people secret & 1 & 2 & 3 & 4 & 5 \\
\hline 4. I act in accordance with known guidance & 1 & 2 & 3 & 4 & 5 \\
\hline \multicolumn{6}{|l|}{ 4. Respectful } \\
\hline 1. I greet my lecturer & 1 & 2 & 3 & 4 & 5 \\
\hline 2. I always talk to senior, lecturer in polite tone & 1 & 2 & 3 & 4 & 5 \\
\hline 3. I respect people decision & 1 & 2 & 3 & 4 & 5 \\
\hline 4. I pay attention when the lecturer is giving lecture & 1 & 2 & 3 & 4 & 5 \\
\hline 5. I can tolerate diversity & 1 & 2 & 3 & 4 & 5 \\
\hline 6. I establish rapport with team members & 1 & 2 & 3 & 4 & 5 \\
\hline 5. Responsibility & SD & D & U & A & SA \\
\hline 1. I try my best to do the task assigned & 1 & 2 & 3 & 4 & 5 \\
\hline 2. I fix the mistake that I commit & 1 & 2 & 3 & 4 & 5 \\
\hline 3. I prepare well before classes & 1 & 2 & 3 & 4 & 5 \\
\hline 4. I am reliable & 1 & 2 & 3 & 4 & 5 \\
\hline 5. I do not commit crime & 1 & 2 & 3 & 4 & 5 \\
\hline 6. I never reject task that were assigned to me if I am capable of & 1 & 2 & 3 & $\begin{array}{l}4 \\
4\end{array}$ & 5 \\
\hline \multicolumn{6}{|l|}{ 6. Compassion } \\
\hline 1. I am considerate to other people & 1 & 2 & 3 & 4 & 5 \\
\hline 2. I always reflect what I have done & 1 & 2 & 3 & 4 & 5 \\
\hline 3. I always care about people & 1 & 2 & 3 & 4 & 5 \\
\hline 4. I am willing to help people in need & 1 & 2 & 3 & 4 & 5 \\
\hline \multicolumn{6}{|l|}{ 7. Communication } \\
\hline 1. I can communicate well orally & 1 & 2 & 3 & 4 & 5 \\
\hline 2. I can express my opinion well & 1 & 2 & 3 & 4 & 5 \\
\hline $\begin{array}{l}\text { 3. I can use body language well if someone doesn't } \\
\text { understand my language }\end{array}$ & 1 & 2 & 3 & 4 & 5 \\
\hline 4. I can write well to the level of others understanding & 1 & 2 & 3 & 4 & 5 \\
\hline 5. I allow to talk without interruption & 1 & 2 & 3 & 4 & 5 \\
\hline \multicolumn{6}{|l|}{ 8. Maturity } \\
\hline 1. I think before making decision & 1 & 2 & 3 & 4 & 5 \\
\hline 2. I can manage relationship with others well & 1 & 2 & 3 & 4 & 5 \\
\hline 3. I am able to think critically & 1 & 2 & 3 & 4 & 5 \\
\hline 4. I do my job in an organized method & 1 & 2 & 3 & 4 & 5 \\
\hline 5. I can recognize and correct my mistake & 1 & 2 & 3 & 4 & 5 \\
\hline 6. I am able to differentiate what is right and what is wrong & 1 & 2 & 3 & 4 & 5 \\
\hline \multicolumn{6}{|l|}{ 9. Self-directed Learning } \\
\hline 1. I am able to learn independently & 1 & 2 & 3 & 4 & 5 \\
\hline 2. I always try to improve myself & 1 & 2 & 3 & 4 & 5 \\
\hline
\end{tabular}

Abbreviations: $\mathrm{SD}$, strongly disagree; $\mathrm{D}$, disagree; $\mathrm{U}$, undecided; $\mathrm{A}$, agree; $\mathrm{SA}$, strongly agree.

Figure SI (Continued) 
C) Open ended questions

What do you mean by professionalism?.

How should professionalism be taught?

How do you learn professionalism?

How should professionalism be assessed?

Figure SI Questionnaire on Fundamental Elements of Professionalism.

Note: Reproduced from Salam et al., $2012 a^{1}$ and $2012 b^{2}$ with permission.

Table SI Grading Scheme for MBBS Programme, UniSZA

\begin{tabular}{|c|c|c|}
\hline Marks Awarded & Grade & Meaning \\
\hline 75 and above & $A+$ & Distinction \\
\hline \multicolumn{3}{|l|}{ *(subject to viva voce) } \\
\hline 70 and above & $A$ & Very good pass \\
\hline $65-69$ & $\mathrm{~B}+$ & Good pass \\
\hline $60-64$ & B & Good pass \\
\hline $55-59$ & $\mathrm{C}+$ & Pass \\
\hline $50-54$ & C & Pass \\
\hline $50 * *$ (For Viva-Voce) & - & Redeemable Failure \\
\hline $0-49$ & $* * * \mathrm{~F}$ & Fail \\
\hline 0 & $\mathrm{~F} / \mathrm{X}$ & Barred from exam \\
\hline 0 & $\mathrm{~F} / \mathrm{TH}$ & $\begin{array}{l}\text { Absent from exam (without } \\
\text { valid reason) }\end{array}$ \\
\hline 0 & $\mathrm{X} / \mathrm{TK}$ & Absent from exam (with valid reason) \\
\hline
\end{tabular}

Notes: *Applicable for professional (PRO) Examination only: a student who obtains 75 and above shall be called for a viva voce and if the student passes the viva voce, the grade shall be upgraded to A+. **Applicable for PRO II Examination only: a student who obtained total marks of $>50 \%$ and theory marks of $45 \%-49.4 \%$ shall be called for viva-voce and if the student passes the vivavoce, the student shall be awarded with grade C. ***Applicable for end of clinical posting (EOP) and PRO II Examination: a student who failed in clinical component shall be given grade $F$.

\section{Reference}

1. Salam A, Song CO, Mazlan NF, Hassin H, Lee LS, Abdullah MH. A pilot study on professionalism of future medical professionals in Universiti Kebangsaan Malaysia (UKM) Medical Centre. Proced Soc Behav Sci. 2012a;60(3):534-540.

2. Salam A, Song CO, Mazlan NF, Hassin H, Lee LS, Abdullah MH. Professionalism of future medical professionals in Universiti Kebangsaan Malaysia (UKM) Medical Centre. Int Med J. 2012b;19(3):224-228.
Advances in Medical Education and Practice

\section{Publish your work in this journal}

Advances in Medical Education and Practice is an international, peerreviewed, open access journal that aims to present and publish research on Medical Education covering medical, dental, nursing and allied health care professional education. The journal covers undergraduate education, postgraduate training and continuing medical education

\section{Dovepress}

including emerging trends and innovative models linking education, research, and health care services. The manuscript management system is completely online and includes a very quick and fair peer-review system. Visit http://www.dovepress.com/testimonials.php to read real quotes from published authors.

Submit your manuscript here: http://www.dovepress.com/advances-in-medical-education-and-practice-journal 